\author{
KONRAD KIEĆ \\ Uniwersytet Szczeciński \\ ORCID: https://orcid.org/0000-0003-4921-6382
}

\title{
Rola PRL w Międzynarodowej Komisji Nadzoru i Kontroli w Wietnamie
}

\section{The role of PPR in International Control Commisson in Vietnam}

\section{Abstract}

In July 1954 by virtue of Geneva Accords International Control Commission was established. This control body functioned in three countries: Vietnam, Cambodia and Laos. Delegations from Poland, Canada and India participated in the works of ICC in Vietnam. Its main task was supervising compliance with the bequest about Vietnam, which were enunciated in Geneva Accords.

PPR delegation in ICC in Vietnam functioned according to guidelines created in Moscow. The process started in May 1955. On $25^{\text {th }}$ of May that year Ministry of Foreign Affairs PPR Stanisław Skrzeszewski held a conversation with ambassador of the USSR in Warsaw Pantelejmon Ponomarenka. Diplomatic representative of the USSR passed on „request” from Wiaczesław Mołotow for the PPR's delegation in ICC in Vietnam to hand over information about development communist's guerrillas acted in South Vietnam.

PPR also tried supporting North Vietnam on the ICC forum through accusing South Vietnam for non-compliance with resolutions of Geneva Agreements. PPR's delegates based their accusations on 14c article of Geneva Agreements. Additionally they tried to prove that Republic of Vietnam belonged to SEATO and actions of US military mission MAAG, TREM was contrary to Geneva Agreements.

Moreover, PPR defended NVN against allegations formulated by South Vietnam. Those were mainly cases related with leading espionage and subversive activity in South. An important activity of the PPR delegation in ICC was slowing down the works of commission when it was about to make some decisions that were unfavorable for the North Vietnam. 
PPR played a role designated by the USSR in ICC, its activity was quite monotonous and the subsequent ministers of foreign affairs of PPR fulfilled it in unchanged form.

Keywords: PPR, International Control Commission in Vietnam, South-East Asia, Cold War

\section{Роль ПНР в Международной Комиссии Надзора и Контроля во Вьетнаме}

\section{Аннотация}

В июле 1954 года на основании соглашений Женевской Конференции была создана Международная Комиссия Надзора и Контроля в Индокитае. Вышеупомянутый орган контроля функционировал в трех государствах: Вьетнаме, Камбодже и Лаосе. В работе МКНИК принимали участие делегации Польши, Канады и Индии. Его главным заданием был надзор над соблюдением записей, касающихся Вьетнама, которые были включены в Женевские Соглашения.

Делегация ПНР действовала в соответствии с руководящими принципами, созданными в Москве. Процесс начался в мае 1955 года. 25 мая министр иностранных дел ПНР Станислав Скшешевский провел беседу с послом СССР в Варшаве Пантелеймоном Пономаренко. Дипломатический представитель СССР передал „просьбу” Вячеслава Молотова о том, чтобы делегация во Вьетнаме передавала информацию о развитии коммунистического партизанского движения, работающего в Южном Вьетнаме.

Польша также пыталась поддержать ДРВ на форуме МКНИК, обвиняя Республику Вьетнам в несоблюдении решений Женевской Конференции. Делегаты ПНР основывали обвинения на статье 14с Женевских Соглашений. Кроме того, они пытались доказать, что Южный Вьетнам тайно принадлежал к SEATO и что действия военных миссий MAAG и TREM противоречат Женевским соглашениям.

Также нужно добавить, что ПНР защищала ДРВ от обвинений, сформулированных Республикой Вьетнам. Это были прежде всего вопросы, связанные с диверсионной и шпионской деятельностью на Юге. Важной деятельностью делегации ПНР в МКНИК во Вьетнаме было затягивание работы Комиссии в то время, когда должны были быть приняты неблагоприятные для ДРВ решения.

ПНР сыграла в МКНИК во Вьетнаме роль, установленную СССР, её деятельность была довольно однообразной, а очередные министры иностранных дел ПНР реализовали ее в неизменной форме.

Ключевые слова: ПНР, Международная Комиссия Надзора и Контроля во Вьетнаме, Юго-Восточная Азия, холодная война 
a początku należy powiedzieć parę słów na temat istniejącego stanu
badań dotyczącego omawianego zagadnienia. Powstało wiele opracowań, monografii oraz artykułów, które dotykają problemu pierwszej wojny w Indochinach oraz dugiej wojny w Indochinach, która częściej występuje w potocznej nazwie wojny w Wietnamie. Trzeba powiedzieć, że wspomniane konflikty poddano analizie zarówno od strony militarnej, politycznej, jak i prawnej. Prezentowano je jako jeden z obszarów rywalizacji mocarstw. Dużo miejsca poświęcono również omówieniu strategii, którą wobec tego region przyjęły oba supermocarstwa oraz Chińska Republika Ludowa. Powstało niewiele prac, w których autorzy dokumentują działalność Międzynarodowej Komisji Nadzoru i Kontroli Wietnamie (dalej MKNiK w Wietnamie) oraz rolę jaką odegrały w niej: Polska, Kanada oraz Indie. Powstałą lukę w badaniach postara się wypełnić niniejszy tekst.

Do napisania artykułu posłużyła metoda krytycznej analizy źródeł. Na podstawie decyzji podejmowanych przez polską delegację w MKNiK w Wietnamie odtworzono główne kierunki działania PRL we wspomnianej organizacji, co pozwoliło określić rolę PRL w Komisji. Ramy chronologiczne pokrywają się z powołaniem do życia Międzynarodowej Komisji Nadzoru i Kontroli w 1954 r. i zajęciem Sajgonu przez oddziały Armii Ludowej Demokratycznej Republiki Wietnamu (dalej DRW) w 1975 roku. Trzeba jednak zwrócić uwagę, że główna aktywność delegacji PRL w MKNiK w Wietnamie miała miejsce w latach 50. oraz 60. XX wieku. Wydarzenia, które rozegrały się w tym okresie pozwalają najlepiej określić rolę PRL w MKNiK w Wietnamie. Z kolei granice terytorialne, przyjęte w niniejszym artykule, obejmują swym zasięgiem dwa państwa wietnamskie (DRW oraz Wietnam Południowy) powstałe w wyniku podzielenia kraju wzdłuż 17 równoleżnika. Zasięg terytorialny został częściowo rozciągnięty na Europę. Artykuł został napisany w układzie problemowym. Zagadnienia, które były poruszane na forum Komisji oraz skargi, które formułowano w oparciu o artykuły układów genewskich z 20 lipca 1954 roku wyznaczały rytm aktywności delegacji PRL w tym organie.

Bazę źródłową do napisania artykułu stanowiły archiwalia zdeponowane w Archiwum Ministerstwa Spraw Zagranicznych. Ze wspomnianego archiwum wykorzystano zespół: Departament V, Międzynarodowa Komisja Kontroli i Nadzoru w Wietnamie. Odnosząc się do źródeł znajdujących 
się w wymienionym archiwum informacje na omawiany temat badawczy znajdują się też w zespole: Depesze: Hanoi i Sajgon. Trzeba mieć jednak na uwadze, że nie oddają one całości obrazu czy problemów związanych $z$ rolą jaką PRL odegrała we wspomnianym organie kontrolnym. Jeśli chodzi dokumenty uzupełniające to użyto te $\mathrm{z}$ The National Archives, zgrupowane w zespołach: Foreign Office: Political Departments: General Correspondence from 1906-1966, Foreign Office and Foreign and Commonwealth Office: South East Asian Department. Materiały pochodzące z The National Archives są cenne, ponieważ pozwalają lepiej zrozumieć decyzje, jakie podejmowała delegacja Kanady w MKNiK i które z kolei przekładały się na aktywność przedstawicieli Polski w opisywanym organie kontrolnym.

Hipoteza badawcza postawiona wobec tematu artykułu ujętego w temacie zakłada, że delegacja PRL odegrała w niej taką rolę na jaką pozwolił jej na to ZSRR. Realizowała ona działania, które wspierały DRW, co odpowiadało interesom Kremla. Jednak później PRL próbowała wykorzystać tę sytuację na swoją korzyść. Opisana postawa nie stanowiła wyjątku, ponieważ pozostali jej członkowie również działali w swoim interesie lub bloku, który reprezentowali. Celem artykułu jest ukazanie głównych kierunków działania PRL w MKNiK na podstawie głównych problemów wiążących się z faktem istnienia obu państw wietnamskich oraz kwestii przestrzegania ustaleń układów genewskich. Poza tym autor postara się odpowiedzieć na pytanie czy aktywność PRL w MKNiK w Wietnamie posiadała istotne znaczenie dla polskiej polityki zagranicznej oraz dyplomacji.

Rozważania rozpocznę od przybliżenia genezy powstania MKNiK w Wietnamie, której historia łączy się z zakończeniem pierwszej wojny indochińskiej. Od 26 kwietnia do 20 lipca 1954 roku w Genewie trwała konferencja, której celem było doprowadzenie do zakończenia wojny jaką Francuzi prowadzili z oddziałami DRW (Adamczyk i Szufelt, 2017, s. 50). Jednym z ważniejszych postanowień, obok podziału Wietnamu wzdłuż 17 równoleżnika, było powołanie do życia organu kontrolnego, którego zadanie koncentrowało się na egzekwowaniu zapisów zawartych w układach genewskich odnoszących się do dwóch państw wietnamskich oraz Laosu i Kambodży. Poza wymienionymi zaleceniami nakazano również stworzyć strefę zdemilitaryzowaną, która wynosiła $4,8 \mathrm{~km}$ po obu stronach linii demarkacyjnej. Siły francuskie musiały wycofać się na południe, a Viet Minhu 
na północ. Ludności dano możliwość swobodnego przemieszczania się pomiędzy strefami w terminie do 300 dni. Nad egzekwowaniem postanowień miała czuwać Międzynarodowa Komisja Nadzoru i Kontroli w Indochinach (Gettelman, Frankliin, Young, Bruce, 1985, s. 73; Ostaszewski, 2000, s. 281). Posiadała ona szerokie kompetencje w obszarze zagadnień politycznych oraz wojskowych.W skład MKNiK wchodzili przedstawiciele: Polski, Kanady oraz Indii (Kosta, 2003, s. 63). Jeszcze jednym istotnym postanowieniem układów był fakt, że w obu częściach Wietnamu zaplanowano przeprowadzić wybory w lipcu 1956, co de facto oznaczałoby koniec funkcjonowania MKNiK w Wietnamie (Ostaszewski, 2001, s. 138). Nie można nie wspomnieć kto sprawował funkcję przewodniczącego całej Komisji. Stanowisko to piastował z ramienia New Delhi Gopalaswami Parthasarthy (Gurtov, 1968, s. 32). Ottawy na szefa swej delegacji mianowała Sherwooda Letta (Canada's Department of External Affairs, http://epe.lac-bac.gc.ca/100/206/301/faitc-aecic/ history/2013-05-03/www.international.gc.ca/department/history-histoire/ dcer/1954/listofpersons-en.asp). Należy odnotować, że przynależność PRL do MKNiK była oznaką prestiżu (Burchardt, Świątkowski, 2015, s. 122).

Warto $\mathrm{w}$ tym miejscu przedstawić proces organizacji polskiej delegacji do MKNiK w Wietnamie. Podstawą do wysłania przedstawicieli PRL do Komisji były przede wszystkim zapisy z układów genewskich z 1954 r., uchwała nr 722/54 Prezydium Rady Ministrów Rządu PRL z dnia 26 października 1954 r. W sprawie utworzenia, wyposażenia, i utrzymania Przedstawicielstw PRL w Międzynarodowych Komisjach Nadzoru i Kontroli nad wykonaniem rozejmu w Indochinach oraz rozkazy Ministra Obrony Narodowej i Ministra Spraw Zagranicznych (Ciechanowski, 2007, s. 50). Pierwszym przewodniczącym delegacji PRL w MKNiK w Wietnamie był Przemysław Ogrodziński (1954-1955), (Słowiak, 2014/2015, t. 7, s. 53-54). Następnie stanowisko to piastował Jerzy Michałowski od dnia 24 sierpnia 1955 roku, kiedy to MSZ przesłało informację o tym fakcie do Ambasady Demokratycznej Republiki Wietnamu w Warszawie (Archiwum Ministerstwa Spraw Zagranicznych dalej AMSZ, Departament V: Międzynarodowa Komisja Nadzoru i Kontroli w Wietnamie 1955, sygn. z. 12, t. 1331, w. 77, s. 1-2). Później pełnili je: Antoni Szymanowski do 7 maja 1957 roku, Władysław Góralski od 15 czerwca 1957 do czerwca 1959 roku, Tadeusz Wiśniewski od czerwca do grudnia 1959 r., Leon Romaniecki (od 1960 do 1963 roku), (AMSZ, 
Departament V: Międzynarodowa Komisja Nadzoru i Kontroli w Wietnamie 10-11 raporty okresowe od 1.02.1959 do 28.02.1962, sygn. z. 22/64, t. 78, w. Wietnam, s. 1), Mieczysław Maneli (1963-1964), Janusz Lewandowski od kwietnia 1966, do maja 1967 roku, (The Telegraph (14.10.2013), Janusz Lewandowski, pobrane z: https://www.telegraph.co.uk/news/obituaries/military-obituaries/10378441/Janusz-Lewandowski.html), Ludwik Klockowski (1970-1973), Bogdan Wasilewski od 1973 do 1975 roku (Dziennik Polski (28-29.01.1973), http://mbc.malopolska.pl/dlibra/plain-content?id=55993). Warto przedstawić sylwetki kilku z wymienionych dyplomatów. Jedną z ciekawszych postaci był Janusz Lewandowski, który został upoważniony przez ówczesnego szefa MSZ do prowadzenia mediacji między DRW a Stanami Zjednoczonymi. Akcje prowadzone przez niego pozwalają stwierdzić, że PRL zamierzała wykorzystać swe członkostwo w MKNiK nie tylko do wspierania rządu w Hanoi. Należy również wspomnieć o pierwszym przewodniczącym Przemysławie Ogrodzińskim, który narzucił delegacji PRL w MKNiK kierunek działania zgodny z wytycznymi otrzymanymi z MSZ, które musiało wypełniać polecenia płynące z Kremla. Na przykładzie pracy Ogrodzińskiego i Lewandowskiego widać ewolucję jaką przeszła polityka PRL prowadzona w wymieniony organie kontrolnym. Ciekawą osobą spośród wymienionych przewodniczących był Mieczysław Maneli. Według części badaczy odgrywał on rolę pośrednika pomiędzy Hanoi a Sajgonem w 1963 roku. Władze DRW przejawiały zainteresowanie jego spotkaniem z Ngô Đình Nhu, który był bratem Prezydenta Republiki Wietnamu. Niektórzy twierdzili, że mógł on zaproponować układ dotyczący neutralizacji Wietnamu Południowego. Jednak bardziej prawdopodobna wydawała się wersja, według której był mediatorem i poszukiwał drogi do rozwiązania konfliktu na bazie zawarcia układu możliwego do zaakceptowania przez obie strony (Gnoinska, 2005, s. 1-3).

W celu lepszego zrozumienia roli delegacja PRL w MKNiK w Wietnamie należy jej działanie interpretować w szerszym kontekście historycznym oraz wskazać czynniki, które wywarły wpływ na jej pracę w rzeczonym organie kontrolnym. Najważniejszym z nich była polityka jaką ZSRR prowadziło wobec DRW. Od 1955 roku Moskwa postanowiła udzielić Wietnamowi Północnemu szerszej pomocy i radziła, aby, z jednej strony, Hanoi respektowało zasady wyznaczone przez układy genewskie $\mathrm{z}$ drugiej zaś sugerowała, by 
komuniści z Północy budowali wpływy wśród ludności Wietnamu Południowego, w szczególności na wsi (Olsen, 1997, s. 40-41). Polska była również potrzebna Hanoi, wywierać wpływ na delegację Indii, której delegat przewodniczył całej Komisji. Indie posiadały charakter państwa neutralnego w MKNIK w Wietnamie, a PRL swymi inicjatywami mogła ją przekonać do popierania rozwiązań korzystnych dla DRW (Olsen, 2006, s. 102).

Wspomniane wypadkowe posiadały przełożenie na rolę jaką PRL odegrała w MKNiK w Wietnamie. Trzeba powiedzieć, że działalność polskich delegatów w Komisji była wytyczona przez Kreml oraz służyła głównie do obrony interesów DRW. Przykładem, który potwierdza postawioną tezę a zarazem wyznacza początek opisywanego procesu to rozmowy jakie odbył 25 maja 1955 roku ówczesny minister spraw zagranicznych PRL Stanisław Skrzeszewski z ambasadorem ZSRR w Warszawie Pantelejmonem Ponomarienką. Z notatki sporządzonej przez szefa polskiego MSZ możemy dowiedzieć się, że odbyły się dwa spotkania dotyczące prac PRL w MKNiK w Wietnamie i oba zainicjowała strona radziecka. Ambasador ZSRR otrzymał polecenie od Wiaczesława Mołotowa, aby poprosił stronę polską o przekazywanie na bieżąco informacji dotyczących rozwoju tzw. „sił demokratycznych” (w rzeczywistości chodziło o partyzantów DRW, którzy przeniknęli na południe) w Wietnamie Południowym. Minister spraw zagranicznych ZSRR poinformował wprost, że chodzi o możliwość udzielenia pomocy wspomnianym grupom, a dane na ten temat przekazywali członkowie polskiej delegacji w MKNiK w Wietnamie. Polacy starali się zachować przy tym ostrożność, dlatego też informacje przesyłano najpierw do centrali MSZ w Warszawie a dopiero potem do Moskwy (AMSZ, Departament V: Międzynarodowa Komisja Nadzoru i Kontroli w Wietnamie. Spr. przygotowania wyborów powszechnych, oraz zjednoczenia Wietnamu, sygn. z. 12, t. 1350, w. 78, s. 1). Na podanym przykładzie widać wyraźnie, że ZSRR wyznaczył PRL pełnienie roli wywiadowczej już na początku działania Komisji.

Kolejnym aktywnościom delegacji PRL w MKNiK w Wietnamie było wysuwanie oskarżeń w oparciu o art. 14c układów genewskich przeciwko Republice Wietnamu. Artykuł ten zakładał, że obie strony wstrzymają się od represjonowania osób, które prowadziły aktywność w trakcie poprzedniej wojny (United Nations, 2018.06.18, Agreement of the Cessation of Hostilities in Viet-Nam 20 July 1954, Article 14c. Pobrane z: https://peacemaker.un.org/ 
sites/peacemaker.un.org/files/KH-LA-VN_540720_GenevaAgreements. pdf).

PRL wspierała również Wietnam Północy na forum Komisji w formułowaniu zarzutów wobec Wietnamu Południowego. Największa liczba skarg rozpatrywana przez $\mathrm{MKNiK}$ w Wietnamie $\mathrm{z}$ tego tytułu miała miejsce w okresie od 1 maja 1957 roku do 30 kwietnia 1958 roku, gdy na forum Komisji wpłynęło ich dwieście cztery. Republika Wietnamu nie odpowiedziała na nie w żaden sposób. Dodatkowo delegacji PRL oraz Indii udało się większością głosów uchwalić zalecenia, według których to komisje powołane przez MKNiK miały sprawdzić czy jej rekomendacje odnoszące się do realizowania swobód zawartych w art. 14 c są wdrażane na Południu (The National Archives, dalej TNA, Foreign Office: Political Departments: General Correspondence from 1906-1966, International Commission for Supervison and Control in Vietnam: reports, sygn. FO 371/136133, s. 7-19). Rząd Wietnamu Południowego nie zastosował się do wymienionych rekomendacji, przez co ucierpiał jego wizerunek a oskarżenia wymierzone w DRW o prowadzenie działań wywrotowych oraz szpiegowskich były nieco stępione. Pomimo działań polskiej dyplomacji na tym polu $\mathrm{MKNiK}$ de facto nie posiadała odpowiednich środków, aby móc egzekwować realizację postanowień układów genewskich. Uwagę na ten fakt zwrócił ambasador Antoni Szymanowski w raporcie złożonym przez polską delegację za okres od 10 września do 31 grudnia 1956 r. (AMSZ, Departament V: Międzynarodowa Komisja Nadzoru i Kontroli w Wietnamie raporty delegacji polskiej 1956, sygn. z. 12, t. 1341, w. 78, s. 27).

Wraz z upływem czasu art. 14c stracił na znaczeniu, jednakże delegacja PRL nie zaniechała swoich działań, aby podtrzymywać oskarżenia oparte o wspomniany przepis na forum MKNiK w Wietnamie. W maju 1959 roku, rząd Diema dostarczyła DRW oraz PRL argumentów do oskarżenia Wietnamu Południowego o łamanie postanowień układów genewskich. Chodzi tu o uchwalenie ustawy 10/59, która pozwalała stawiać przed trybunałami wojskowymi osoby oskarżone o dywersję. Trybunały te wydawały surowe wyroki przeważnie zesłanie na ciężkie roboty lub wyroki śmierci. Co więcej, nie obowiązywała w tym przypadku procedura odwołania się do sądu wyższej instancji. Delegat PRL w MKNiK w Wietnamie porównał ją do prawa uchwalonego w 1956 roku, które zakazało działalności Partii 
Komunistycznej w Wietnamie Południowym. Polska delegacja wykorzystała tę sytuację wysuwając oskarżenia wobec Republiki Wietnamu na podstawie art. 14a układów genewskich. Zakazywał on powoływania trybunałów wojskowych obu stronom, ponieważ dopuszczano istnienie wyłącznie tych o charakterze cywilnym. Większością głosów strona polska i indyjska dnia 31 lipca 1959 roku, zdecydowały, że MKNiK w Wietnamie powinna zająć się wspomnianym prawem. Inny pogląd wyraziła delegacja Kanady, wychodząc z założenia, że wymieniona ustawa była sprawą wewnętrzną Republiki Wietnamu a Komisja nie posiada w tym wypadku prawa do interwencji. Ostatecznie jednak Hindusi częściowo cofnęli swe poparcie dla PRL w tej kwestii. 23 października 1959 roku PRL skierowała tę sprawę do właściwej komisji i bezpośrednio oskarżyła Wietnam Południowy (Sardesai, 1968, s. 197-198).

Sprawą, która była również związana z rzekomym naruszeniem przez Wietnam Południowy art. 14c pozostawała kwestia rozstrzygnięcia odpowiedzialności za śmierć więźniów w Phu-Loi, która miała miejsce w grudniu 1958 roku. We wspomnianej miejscowości oddalonej o 33 kilometry od Sajgonu znajdowało się więzienie dla aktywnych działaczy komunistycznych lub osób, które identyfikowały się z tą ideologią. Na przełomie roku 1958/1959 zmarło tam tysiąc osadzonych z ogólnej liczby sześciu tysięcy. DRW postanowiło wykorzystać to zdarzenie i wzmocnić swój przekaz propagandowy oskarżając rząd Diema o dokonanie masakry. Inne zdanie na ten temat posiadali obserwatorzy z ambasady brytyjskiej w Sajgonie, według których doszło do skażenia żywności, a nie celowego użycia trucizny. Wspomniana sytuacja miała miejsce, ponieważ władze więzienia dopuściły się zaniedbania (Guan, 2012, s. 99). Delegacja PRL w MKNIK w Wietnamie zareagowała na te wydarzenia i zgłosiła wniosek na forum Komisji, aby wysłać do Phu-Loi grupę, która miałaby dokonać inspekcji. Delegacja kanadyjska odrzuciła taką możliwość, a Indie poparły ją do pewnego stopnia dlatego, że nie wykluczały możliwości sformowania takiej grupy w przyszłości (AMSZ, Departament V: Międzynarodowa Komisja Kontroli i Nadzoru w Wietnamie, Mat.dot. masowego mordu więźniów Phu-Loi obozu koncentracyjnego w Wietnamie Południowym 1959, Notatka S. Stradowskiego skierowana do Min. M. Naszkowskiego, sygn. z. 12, t. 1347, w. 78, s. 1-4). Ciekawym epizodem, który wiąże się z opisanymi wydarzeniami jest list protestacyjny wysłany przez 
Nguyên Giáp dnia 28 stycznia 1959 roku, do Komisji. DRW winę za śmierć osadzonych przypisała Stanom Zjednoczonym, jednakże w tym wypadku PRL posiadała odmienne zdanie (AMSZ, Departament V: Międzynarodowa Komisja Nadzoru i Kontroli w Wietnamie, Mat.dot. masowego mordu więźniów Phu-Loi obozu koncentracyjnego w Wietnamie Południowym 1959, List generała Nyguen-Giapa Gł. Dow. Ludowej Armii Wietnamu do jego Ekscelencji Pana Ambasadora Ansari Przew. M.K.N.I Kw Wietnamie, z. 12, t. 1347, w. 78, s. 10-13). Na podanych przykładach możemy zauważyć, że PRL wspierała aktywnie DRW w Komisji, zgłaszając oraz przegłosowywując wnioski niekorzystne dla Republiki Wietnamu.

Omawiając kolejne działania PRL w MKNiK należy wskazać, że nadzór Komisji nad kontrolą przewozu broni oraz personelu wojskowego w Republice Wietnamu był ograniczony ze względu stanowiska rządu Diema. Nie uznawał on porozumień genewskich ani nie zamierzał ich wypełniać. Co nie zmienia faktu, że delegacja PRL działała w sposób stronniczy (Tebinka, 2010, s. 226).

Delegacja polska w MKNiK działała również zgodnie z zaleceniami Moskwy w odniesieniu do formułowania oskarżeń dotyczących rzekomej przynależności Wietnamu Południowego do South East Asia Treaty Organization (dalej SEATO) oraz zaangażowania Stanów Zjednoczonych we wspomnianym państwie. Tym razem powoływano się na art. 19 układów Genewskich, który zabraniał stronom wstępować do paktów wojskowych. Aktywne zaangażowanie polskiej strony przyniosło efekty, ponieważ na forum Komisji udało się w 1956 roku dowieść, że Republika Wietnamu nie wykonuje postanowień odnoszących się do zakazu wprowadzania sprzętu oraz personelu wojskowego. Objawiało się to tym, że personel amerykański oraz samoloty tego kraju lądowały bez zezwolenia Komisji na terytorium Południa. Skutkiem tego było wszczęcie szeregu kontroli w sprawie nielegalnego importu borni. Co więcej, działania PRL w tej kwestii przyczyniły się do tego, że rozciągnięto kontrolę nad lotniskami Południa oraz poprawiono nadzór nad lotniskiem w Sajgonie (AMSZ, Departament V: Międzynarodowa Komisja Nadzoru i Kontroli $w$ Wietnamie w Wietnamie, raporty delegacji polskiej 1956, sygn. z. 12, t. 1341, w. 78, s. 11-13). Wracając do oskarżeń z art. 19, które delegacja PRL zgłaszała w M.K.N.I.K w Wietnamie, należy powiedzieć, że w latach 1956-1957 wysłała w tej sprawie ponad dwadzieścia listów do Komisji. Oskarżała ona Wietnam 
Południowy o to, że potajemnie jest członkiem SEATO, a Stany Zjednoczone, wspierając militarnie Południe, złamały postanowienia układów genewskich. Ówczesny przewodniczący delegacji PRL w MKNiK w Wietnamie Władysław Góralski przytaczał liczby dotyczące zwiększenia stanu personelu wojskowego Stanów Zjednoczonych w Wietnamie Południowym. 1 października 1956 roku wynosił on 1700 osób, ale w okresie od 1956 do 1957 roku przewinęło się przez ten kraj ponad 2300 wojskowych. Zamierzał on również przekonać pozostałych delegatów w Komisji, że to właśnie ona powinna zająć się tą sprawą. Swą argumentację opierał również na art. 37, w myśl którego MKNiK w Wietnamie mogła wszcząć postępowanie na wniosek stron (AMSZ, Departament V: Międzynarodowa Komisja Nadzoru i Kontroli w Wietnamie, Projekt wystąpienia W. Góralskiego przesłany do Witolda Rodzińskiego, sygn. z. 12, t. 1344, w. 78, s. 1-12).

Jeszcze jeden aspekt, który pojawiał się wokół omawianych zagadnień to kwestia funkcjonowania dwóch amerykańskich misji wojskowych na terenie Republiki Wietnamu, czyli MAAG oraz TREM. Pierwsza z nich, której pełna nazwa brzmiała Military Assistance Advisory Group, powstała na początku lat 50. XX wieku i liczyła początkowo 342 osoby, a ich dowódcą był gen. Samuel T. Williams. Jej zadaniem było wyszkolenie armii Wietnamu Południowego (Westheider, 2007, s. 7). Delegacja PRL próbowała udowodnić, że istnienie MAAG jest niezgodne z układami genewskimi, choć sformowano ją dużo wcześniej na mocy układu o wzajemnej pomocy z dnia 23 grudnia 1950 roku zawartego pomiędzy Stanami Zjednoczonymi a państwami Azji Południowo-Wschodniej. Nie udało się jednak doprowadzić do wyprowadzenia wspomnianej misji z Republiki Wietnamu.

Inaczej sprawa wyglądała z TERM (skrót od Temporary Equipment Recovery Misson), która powstała w 1956 roku, czyli już po podpisaniu układów genewskich, co wzbudzało kontrowersje, które delegacja PRL wykorzystała na forum MKNIK w Wietnamie. Komisja rozpatrywała tę sprawę w czterech raportach corocznych, które powstały w okresie od 11 grudnia 1955 roku do 31 stycznia 1959 roku. Sukcesem PRL było wystosowanie listu No. OPS/ III/5/B/8210 z dnia 23 grudnia 1958 roku, do rządu Republiki Wietnamu, w którym rekomendowano wycofanie sprzętu oraz ludzi wchodzących w jej skład. Przedstawiciel polskiej delegacji stwierdził, że po tym terminie TREM powinna ulec rozwiązaniu. $\mathrm{MKNiK} w$ Wietnamie w przygotowanym raporcie 
uznała, że rząd Diema nie zastosował się do rekomendacji. Wietnam Południowy w liście z 29 października 1959 roku (nr 5800/PDVN/CT/TD/11) utrzymywał, że TREM powinien zaprzestać swej działalności do końca 1960 roku. Delegaci Kanady oraz Indii przystali na termin podany przez Sajgon, jednakże PRL utrzymywała, że MKNiK w Wietnamie wykazała się przejawem dobrej woli, a polska delegacja nalegała, aby doszło do rozwiązania misji w sposób możliwie najszybszy (AMSZ, Międzynarodowa Komisja Nadzoru i Kontroli w Wietnamie, 10-11 raporty okresowe od 01.02.1959 do 28.02.1962, sygn. z. 22/64, t. 78, w. Wietnam, s. 28-30).

Delegacja PRL na forum MKNiK w Wietnamie starała się przede wszystkim oddalać zarzuty, które rząd Diema formułował wobec Hanoi, a dotyczyły one prowadzenie przez Północ działań o charakterze wywrotowym na terenie Wietnamu Południowego. Sprawa była poważna. Jeżeli Komisja rozpatrzyłaby je, to wówczas ucierpiałby w znacznej mierze prestiż Północy, co byłoby sukcesem propagandowym Republiki Wietnamu. Problem ten stał się przedmiotem dyskusji pomiędzy ówczesnym szefem delegacji PRL w MKNiK w Wietnamie Władysławem Góralskim a dyrektorem Departamentu V MSZ Edwarda Sułczańskim. Drugi z nich proponował, by zgodzić się z propozycją Indii przedstawionej stronie polskiej, według której należało zachęcić Diema do współpracy z Komisją i uzyskać od niego zgodę na wysłanie ruchomych grup w celu dokonania inspekcji (chodziło również o to, by nie zawiązał się sojusz Kandy i Indii). Następnie wykazanoby, że nie jest prowadzona przez DRW działalność dywersyjna, co ośmieszyłoby Wietnam Południowy oraz podważyło zasadność argumentu, że Południe potrzebuje wsparcia SEATO. Ambasador Góralski nie zgodził się z tym poglądem. Według niego pojedyncze zagłosowanie w Komisji przeciwko Hindusom nie złamałoby współpracy obu państw. Przyniosłoby ono szkody DRW oraz całemu obozowi socjalistycznemu. Nie należało też okazywać słabości Indiom, aby państwo to nie wyszło z założenia, że jest uprawnione do wywierania nacisku na delegację PRL w każdej sprawie. Słuszność tego postępowania potwierdzała sytuacja, gdy delegacja PRL nie zagłosowała za przyjęciem projektu wysuniętego przez delegatów tego państwa, a które dotyczyły zmniejszenia liczby oficerów w grupach. Następnie Indie wycofały inne pomysły skierowane przeciwko DRW. Góralski radził, aby skierować tę kwestię do Komitetu Prawnego i tam ją „pogrzebać” (AMSZ, Departament V: 
Międzynarodowa Komisja Nadzoru i Kontroli w Wietnamie dot. Komisja a skargi Diema o subwersje wyprawiona rzekomo przez stronę Pótnocna, 1957-58, List Władysława Góralskiego skierowany do Edwarda Sułczańskiego Dyrektora Departamentu V MSZ z dnia 14 grudnia 1957 r., sygn. z. 12, t. 1342, w. 78, s. 2-4). Dnia 16 stycznia 1958 roku, Sułczański wysłał list do Góralskiego, w którym zgadzał się z postawionymi przez niego tezami jednakże uważał, że należy dopuścić możliwość kompromisu w pewnych sprawach, np. żeby Komisja rozpatrywała te zarzuty każdorazowo i żeby czynić analogicznie ze skargami wnoszonymi przez DRW jak proponował Michałowski. Dyrektor Departamentu V MSZ nie uważał, by MKNiK w Wietnamie była uprawniona do rozpatrywania skarg związanych z subwersją, jak proponowały Indie, jednakże chciał wytworzyć sytuację korzystną dla PRL poprzez doprowadzenie do kompromisu w tej kwestii. Dodatkowo uważał, że nie można w żaden sposób wmanewrować się w konflikt z Hindusami w Komisji (AMSZ, Departament V: Międzynarodowa Komisja Nadzoru i Kontroli $w$ Wietnamie dot. Komisja a skargi Diema o subwersje wyprawiona rzekomo przez stronę Pótnocna 1957-58, List Edwarda Sułczańskiego skierowany do Władysława Góralskiego z dnia 16 stycznia 1958 r., sygn. z. 12, t. 1342, w. 78, s. 5). Ostatecznie w tej sprawie rację posiadał Edward Sułczański, ponieważ Indie nie poparły raportu Komitetu Prawnego, który zalecał rozpatrywać skargi dotyczące prowadzenia działalności szpiegowskiej i wywrotowej jako całości. Od 1957 roku każdą sprawę tego rodzaju Komisja badała osobno, co wydłużało proces decyzyjny w MKNiK w Wietnamie. Pomimo oskarżenia te nie przestały napływać i w latach $1955-1960$ było ich ponad 80 (AMSZ, Departament V: Międzynarodowa Komisja Nadzoru i Kontroli w Wietnamie, Notatka amb. Wiśniewskiego $z$ dnia 23 lipca 1960 roku przesłana do Departamentu $V$, sygn. z. 12, t. 1348, w. 78, s. 9-12). Epizodem, który miał miejsce w 1956 r., a który warto odnotować, była sprawa tzw. „Grupy 80”. Wówczas Wietnam Południowy skierował skargę do Komisji przeciwko Hanoi, w której to oskarżono Wietnam Północny o przetrzymywanie jeńców wojennych. W ciągu kilku miesięcy 1956 roku przesłuchano ponad dwudziestu świadków, którzy swymi zeznaniami obciążyli DRW. Jednakże w tym samym czasie delegacja PRL w MKNiK w Wietnamie zorganizowała swoje przesłuchania oraz pozyskała dokumenty z Wietnamu Północnego, dzięki którym udało się odrzucić skargę na forum Komisji (AMSZ, Departament V: Międzynarodowa 
Komisja Nadzoru i Kontroli w Wietnamie, raporty delegacji polskiej 1956, Raport okresowy od 1 stycznia do 9 września 1956 r. sporzadzony przez Jerzego Michałowskiego sygn. z. 12, t. 1341, w. 78, s. 12-13). Należy wskazać, że po fiasku zorganizowania wyborów powszechnych oraz zjednoczenia obu państw wietnamskich w 1956 roku, nasiliła się działalność Vietkongu (Dmochowski, 1991, s. 62-63). Od tego czasu spływało coraz więcej skarg na DRW odnośnie prowadzenia działalności wywrotowej.

Kolejnym obszarem aktywności delegacji PRL w MKNiK w Wietnamie, który określał jej rolę we wspomnianym organie kontrolnym było opóźnianie prac, a w szczególności, gdy zamierzano wydać decyzje niepomyślne dla Hanoi. W 1960 roku delegacja kanadyjska zgłaszała coraz więcej zarzutów wobec DRW z mocy art. 25 układów genewskich, w których oskarżano ten kraj o brak współpracy z Komisją. Dzięki działaniom PRL udało się Wietnamowi Północnemu uniknąć poważnych kłopotów w MKNiK. Pomimo tego raz użyto art. 25, kiedy DRW nie zgodził się na przeprowadzenie inspekcji na jednym z lotnisk. Odmowa ta posiadała konkretne powody związane z importowaniem broni przez wspomniane państwo. Dodatkowo w 1960 roku, obserwacją objęto port w Hajfongu oraz miasto Láo-Cai, które było położone przy granicy z Chińską Republiką Ludową. Delegacja polska odnotowała również, że w przeciągu trzech pierwszych miesięcy 1960 roku było więcej inspekcji aniżeli w poprzednich pięciu latach. Niekorzystna dla PRL okazała się współpraca, jaką nawiązały ze sobą delegacje Indii i Kanady. Dodatkowo ignorowano zapisy polskich oficerów, które dotyczyły zbrojeń, jakie czynił Wietnam Południowy (AMSZ, Departament V: Międzynarodowa Komisja Nadzoru i Kontroli w Wietnamie, Raport delegacji Polski za 1960 r., sygn. z. 12, t. 1348, w. 78, s. 1-4).

W momencie, gdy delegacji PRL coraz trudniej było przekonywać swoich partnerów w Komisji do swego stanowiska postanowiła ona spowodować obstrukcję w pracy całej MKNiK w Wietnamie (TNA, Foreign Office and Foreign and Commonwealth Office: South East Asian Department, International Control Commission: United Kingdom policy, sygn. FCO 15/1277, s. 1). Działania te okazały się na tyle skuteczne, że w 1965 roku Kanada wobec niemożności zapewnienia przez Komisję neutralności Laosu postanowiła ograniczyć swe zaangażowanie poprzez wycofanie części personelu wojskowego z Wietnamu oraz całkowicie zakończyć swą aktywność w Kambodży 
i Laosie (Kerr, 1997, s. 126-128). Władze Kanady uważały, że prace wspomnianych organów nie przynoszą zamierzonych efektów, a koszt utrzymania personelu był dość wysoki. Zmian w tej materii domagało się również samo społeczeństwo kanadyjskie. W 1964 roku Kanada posiadała pięciu inspektorów wojskowych w DRW, pięciu w Republice Wietnamu oraz jednego w strefie zdemilitaryzowanej. Od 1 stycznia 1965 roku pozostawiono po dwóch inspektorów w Hanoi oraz Sajgonie. Od września natomiast pozostali oni tylko w samym Wietnamie. Nie było ich już w Wientain oraz Phnom Penh (TNA, Foreign Office: Political Demaptments: General Correspondence from 1906-1966, Canada attitude toward the International Control Commission after a visit by a team inspection to Vietnam, Laos and Cambodia, sygn. FO 371/175094, s. 11-13) Na opisanym przykładzie widać, że działania PRL dotyczące blokowania prac w Komisji okazały się skuteczne. Doprowadziły bowiem do zniechęcenia strony kanadyjskiej, gdyż organ ten nie był zdolny wyegzekwować od DRW, aby Hanoi nie podejmowało działań prowadzących do naruszenia neutralności Laosu. Dodatkowo wobec nieudolnych działań MKNiK w Wietnamie w sprawie zachowania neutralności Laosu, bombardowania amerykańskie według Londynu oraz Ottawy wydawały się zasadne (TNA, Foreign Office and Foreign and Commonwealth Office: South East Asian Department, International Control Commission, International Control Commission: Soviet policy, FCO 15/1276, s. 13). Z drugiej strony akcje te wyglądały na niezwykle nerwowe oraz ofensywne w oczach opinii międzynarodowej.

Wartym odnotowania wątkiem jest mianowanie Janusza Lewandowskiego w kwietniu 1966 roku na nowego przewodniczącego polskiej delegacji w MKNiK w Wietnamie. Ówczesny minister spraw zagranicznych PRL Adam Rapacki widział w nim postać, która będzie stanowić łącznik pomiędzy Waszyngtonem i Hanoi, które nie utrzymywały normalnych stosunków dyplomatycznych. Dodatkowo Rapacki potajemnie dał mu prawo do szukania pokojowego rozwiązania konfliktu w Wietnamie poza jego normalną pracą w Komisji [Hershberg, (15.01.2012), Cracking a Vietnam War Mystery, https://nsarchive2.gwu.edu//NSAEBB/NSAEBB369/ index.htm\#_ftn8]. Lewandowski przystąpił do działania i pozyskał kilka interesujących informacji od strony włoskiej, a mianowicie od ambasadora Republiki Włoskiej w Sajgonie Giovanniego D’Orlandi. Opowiedział mu 
o rozmowach, jakie toczyli minister spraw zagranicznych Włoch Amintore Fanfani z Williamem Harrimanem, gdzie Stany Zjednoczone były w tym momencie bardziej zainteresowane zakończeniem konfliktu w Wietnamie. Lewandowski dodatkowo spotkał się z ambasadorem Stanów Zjednoczonych w Sajgonie Henry Cabotem Lodge'm u Orlandiego w celu wysondowania jego poglądu na temat rozwiązaniu konfliktu. Polski rozmówca zaproponował, że gestem dobrej woli ze strony Waszyngtonu byłoby zaprzestanie bombardowań lub choćby częściowe wycofanie wojsk z terenu Republiki Wietnamu [Hershberg, (15.01.2012), Cracking a Vietnam War Mystery: Document 4: Cable from Polish ICC Mission, Saigon (Lewandowski) to Polish Foreign Ministry (Michalowski), ciphergram no. 14596, 14 November 1966, https://nsarchive2.gwu.edu//NSAEBB/NSAEBB369/index.htm\#_ftn8]. Plan, który został wymyślony przez Lewandowskiego i dotyczył zawarcia pokoju w Wietnamie nosił nazwę „Marigold” (Brown, 1991, s. 78). Informacje te wywołały zainteresowanie w Warszawie, dlatego Adam Rapacki wraz z Jerzym Michałowskim wybrali się do Sofii. W dniach od 18 do 19 listopada 1966 roku odbywał się tam Zjazd Komunistycznej Partii Bułgarii, na którym obecny był również ówczesny przywódca ZSRR Leonid Breżniew oraz minister spraw zagranicznych DRW Nguyen Duy Trinh, z którym Rapacki i Michałowski spotkali się i omówili wspomniane zagadnienie. Minister spraw zagranicznych PRL poinformował ówczesnego I sekretarza KC KPZR o rozmowach jakie ambasador PRL w Hanoi odbył z Lodge’m. Breżniew wydawał się być zadowolony z rozwoju sytuacji, choć uważał, że rozmowy z Wietnamczykami są czasem bezcelowe, gdyż pomimo deklaracji ze strony niektórych pojedynczych osób, ostateczne decyzje władz DRW znacznie różnią się od zapewnień Hershberg (15.01.2012), Cracking a Vietnam War Mystery: Document 6: Excerpt from Polish cable from Sofia, Bulgaria, reporting on conversation between Polish Foreign Minister Adam Rapacki and Soviet leader Leonid I. Brezhnev, November 18, 1966, https://nsarchive2.gwu. edu//NSAEBB/NSAEBB369/index.htm\#_ftn8). Adam Rapacki 19 listopada 1966 r. również odbył rozmowę z ministrem spraw zagranicznych DRW. Podczas spotkania szef polskiego MSZ przekonywał, że na obecnym etapie Amerykanie biorą rzecz na poważnie i Lodge nie działał na własną rękę. Zaufał on dobrej woli Waszyngtonu i odnotował, że Stany Zjednoczone były w tej kwestii elastyczne jak nigdy wcześniej. Dodatkowo według polskiego 
rozmówcy administracja prezydenta Johnsona mogła podjąć takie zabiegi, ponieważ zbliżały się wybory prezydenckie, a omawianą kwestię należało w jakiś sposób uregulować, choćby na drodze negocjacji pokojowych. Innym powodem mogło być przypuszczenie, że wojny w szybki sposób nie da się zakończyć, co z kolei wiązałoby się z większym zaangażowaniem militarnym. Rapacki odnotował również, że na spotkaniu z Nguen-Duy-Trinhem pojawiła się sprawa MKNiK, którą polski minister uznał za mało istotną [Hershberg, (15.01.2012), Cracking a Vietnam War Mystery: Document 8: Polish memorandum of conversation between Polish foreign minister Adam Rapacki and North Vietnamese foreign minister Nguyen Duy Trinh leader, Sofia, Bulgaria, November 19, 1966, https://nsarchive2.gwu.edu// NSAEBB/NSAEBB369/index.htm\#_ftn8]. O zainteresowaniu Hanoi polską inicjatywą może świadczyć fakt, że Lewandowski spotkał się z premierem DRW Phạm Văn Đồng dnia 25 listopada 1966 r. Ocenił on pozytywnie rolę PRL w Komisji oraz to, co robi na rzecz DRW.Zgodził się z Lewandowskim, że należy dać czas Stanom Zjednoczonym na to, by mogły zastanowić się nad pokojowym rozwiązaniem konfliktu. Powiedział, że zaprzestanie bombardowań jest punktem początkowym do prowadzenia rozmów między stronami (Hershberg, (15.01.2012), Cracking a Vietnam War Mystery: Document 11: Ciphered telegram from Lewandowski in Hanoi reporting on Conversation with North Vietnamese Premier Pham Van Dong, November 25, 1966, https://nsarchive2.gwu.edu//NSAEBB/NSAEBB369/index.htm\#_ftn8).Plan ten jednak nie powiódł się, ponieważ ostatecznie w Waszyngtonie zdecydowano się rozszerzyć zaangażowanie militarne, wobec czego plany zawarcia pokoju zakończyły się fiaskiem (Pasztor, 2017, s. 120).

PRL jednoznacznie pokazała swą stronniczość w MKNiK w 1968 roku, gdy pod koniec stycznia tego roku zakonspirowani komuniści z Wietnamu Północnego przeprowadzili uderzenie na szeroką skalę w Wietnamie Południowym, gdzie do walk doszło m.in. w Sajgonie. Atak ten przeszedł do historiografii pod nazwą ofensywy Tet (Benken, 2016, s. 120-121). MKNiK w Wietnamie postanowiła zbadać trzy miejsca, gdzie doszło do wspomnianej ofensywy, a wniosek wpłynął ze strony Republiki Wietnamu. Komisja rozpatrzyła go pozytywnie, a wojskowi Kanady i Indii dokonali inspekcji, natomiast Polacy odmówili wzięcia udziału w pracach. Grupa badała przede wszystkim jedno z ważniejszych miejsc ataku partyzantki komunistycznej 
czyli Nah Trang. Uzyskano tam dowody, które potwierdzały jednoznacznie, kto ponosi winę za wspomniane ataki oraz że DRW prowadziło działalność szpiegowsko-wywrotową na terenie Republiki Wietnamu. Po przebadaniu punktów, w których doszło do ataków grupa udała się do więzienia, gdzie siedmiu osadzonych zgodziło się dobrowolnie zeznawać na temat wydarzeń, które miały miejsce. Wszyscy przyznali się, że prowadzili infiltrację na rzecz DRW w latach 1963-1967. Co więcej, pokazali drogę jaką przebyli z Wietnamu Północnego do wskazanego miejsca i okazało się, że przemierzali oni terytorium Kambodży oraz Laosu, wobec czego zarzuty o pogwałceniu neutralności tego drugiego państwa były zasadne. Trzech z siedmiu osadzonych stwierdziło nawet, że służyli w 325. Dywizji Armii DRW. Podobne zeznania składali ci więźniowie, którzy brali w 1968 roku udział w szturmie na Sajgon. Kanadyjczycy odnotowali jeszcze, że statki, które przypłynęły do Nah Trang wyruszyły z Hajfongu, były widoczne na radarach amerykańskich oraz wiozły na swoich pokładach broń, amunicję oraz medykamenty dla oddziałów Vietkongu działających w Wietnamie Południowym. Dodatkowo jeden z Wietnamczyków złapany po szturmie na Sajgon utrzymywał, że przesunięto go na teren Republiki Wietnamu jeszcze w 1954 roku [TNA, Foreign Office and Foreign and Commonwealth Office: South-East Asian Department, Indochina, I.C.C.'s political affairs (multilateral), Vietnam Commission Raports, sygn. FCO 15/253, s. 52-53). Oczywiście należy zadać pytanie czy zeznania uzyskano od więźniów faktycznie w sposób dobrowolny oraz czy nie powiedzieli oni tego czego oczekiwała od nich Republika Wietnamu oraz śledczy z Kanady oraz Indii. Biorąc jednak pod uwagę inne fakty należy przyjąć, że relacje osadzonych były prawdziwe nawet, gdy za ich ujawnienie zamierzali uzyskać korzyści osobiste.

Podsumowując niniejsze rozważania na temat roli jaką PRL odegrała w MKNiK w Wietnamie trzeba powiedzieć, że realizowała ona plan nakreślony w Moskwie, który tyczył się tej części globu. Właściwie wszystkie delegacje wchodzące w skład opisywanego organu kontrolnego realizowały na jej forum interesy bloku, do którego przynależały. Dotyczyło to zarówno PRL, Kanady oraz Indii. Warto dodać, że Kanada reprezentowała interesy państw zachodnich: początkowo Francji, a następnie Stanów Zjednoczonych (Bronsan, 1975, s. 124; Schreiber, 2012; s. 3). Pomimo licznych kontrowersji związanych z działalnością PRL w tym organie, w 1973 roku na podstawie 
układów paryskich została członkiem zreorganizowanej Komisji, która przyjęła nazwę Międzynarodowej Komisji Kontroli i Nadzoru w Wietnamie (Majewski, 2006, s. 25).

Sytuacja ta wynikała z zimnowojennego podziału świata, przez co MKNiK traktowano w sposób instrumentalny. Dodatkowo PRL pragnęła ukazać swą użyteczność względem Moskwy oraz pokazać, że jest jednym z aktywniejszych państw, które wchodzą w skład bloku wschodniego (Thakur, 1984, s. 261-262). Trzeba dodać, że Polska poprzez działalność w Komisji była wiernym sojusznikiem DRW, ale nie odniosła $\mathrm{z}$ wytworzonej sytuacji większych korzyści poza tymi związanymi ze sprawami prestiżu (Benken, 2014, s. 99). Należy powiedzieć na koniec, że polityka PRL w MKNiK w Wietnamie praktycznie była jednostajna, mimo iż w latach 1954-1975 ministrami spraw zagranicznych PRL byli kolejno: Stanisław Skrzeszewski, Adam Rapacki oraz Stefan Jędrychowski.

\section{MGR KONRAD KIEĆ}

Instytut Historii i Stosunków Międzynarodowych Uniwersytetu Szczecińskiego

Wydział Humanistyczny

Uniwersytet Szczeciński

ul. Krakowska 71-79, 71-017 Szczecin

kieckonrad@gmail.com

\section{Bibliografia}

\section{Archiwalia}

Archiwum Ministerstwa Spraw Zagranicznych:

Departament V

Międzynarodowa Komisja Nadzoru i Kontroli w Wietnamie

The National Archives:

Foreign Office and Foreign and Commonwealth Office: South-East Asian Department Foreign Office: Political Departments: General Correspondence from 1906-1966

\section{Opracowania}

Adamczyk, M., Szuflert, O. (2017). Indochiny w amerykańskiej polityce powstrzymywania do 1963 roku. Poznań: Media-Expo.

Benken, P. (red.). (2014). Pomoc Polskiej Rzeczpospolitej Ludowej dla Wietnamu Północnego podczas II wojny indochińskiej - zarys problematyki. W: B. Benken, J. Słowiak, Studia nad Indochinami. Zabrze-Tarnowskie Góry: Inforteditions. 
Benken, P. (2016). Ofensywa Tet. Studium militarno-polityczne. Szczecin: Instytut Pamięci Narodowej - Komisja Ścigania Zbrodni przeciwko Narodowi Polskiemu, Oddział w Szczecinie.

Bronsan, V. (1975). The International Commission for Vietnam; the diplomatic and military context. Vancouver: The University of British Columbia.

Brown, T. (1991). War and aftermath in Vietnam. London: Routledge.

Burchardt J., Świątkowski, P. (1985), Szpieg, który wiedział za mało. Tajemnice z kontrwywiadu PRL. Poznań: Wydawnictwo Poznańskie.

Ciechanowski, G. (2007). Żołnierze polscy $w$ misjach i operacjach pokojowych poza granicami kraju w latach 1953-1989. Toruń: Wydawnictwo Adam Marszałek.

Dmochowski, A. (1991). Wietnam. Wojna bez zwycięzców. Kraków: Wydawnictwo „Europa”.

Gnoinska, M. (2005). Poland and Vietnam 1963: New Evidences on Secret Communist Diplomacy and The „Maneli Affair”, Cold War International History Project Working Paper Series, 45, 1-3.

Guan, A. (2012). Vietnamese Communists' Relations with China and the Second Indochina Conflict, 1956-1962. Jefferson: MacFarland.

Kerr, J.L. (1997). „Honest Broker”? Canada and The International Commission for Supervision and Control: Cambodia: 1954 to 1964. Ottawa: Calerton University.

Kosta, A. (2003). Amerykańska polityka $w$ Wietnamie po konferencji w Genewie. Warszawa, Częstochowa: Pat.

Majewski, P. (red). (2006). Polskie Dokumenty Dyplomatyczne. Dokument nr 7. Warszawa: Wydawnictwo Polskiego Instytutu Spraw Międzynarodowych.

Olsen, M. (1997). Solidarity and National Revolution. The Soviet Union and the Vietnamese Communists 1954-1960. Forsvarsstudier 4, 40-41.

Olsen, M. (2006). Soviet-Vietnam Relations and the Role of China, 1949-64, changing alliances. London, New York: Routledge.

Ostaszewski, P. (2000). Najdłuższy konflikt powojennego świata 1945-1975, Warszawa: DiG.

Ostaszewski, P. (2001). Polska a konflikt wietnamski 1954-1975, Polski Przeglad Dyplomatyczny, 1(1), 138.

Pasztor, M. (2017). Nieudana próba mediacji polsko-włoskiej w konflikcie wietnamskim w latach 1965-1967. Przeglad Historyczno-Wojskowy, 3(261), 120.

Sardesai, D. (1968). Indian Foreign Policy in Cambodia, Laos, \& Vietnam, 1947-1964. Berkeley: University of California Press.

Słowiak, J. (2014/2015). Working with the Enemy: Polish Perceptions of the Canadian Delegation in the International Commission for Supervison and Control in Vietnam. TransCanadiana, 7, 53-54.

Tebinka, J. (2010). Uzależnienie czy suwerenność? Odwilż październikowa $w$ dyplomacji Polskiej Rzeczpospolitej Ludowej 1956-1961. Warszawa: Wydawnictwo Neriton.

Thakur, R. (1984). Peacekeeping in Vietnam: Canada, India, Poland, ant the International Commission. Edmonton: The University of Alberta Press.

Westheider, J. (2007). The Vietnam War. Wesport, Connecticut, London: Greenwood Publishing Group. 


\section{Netografia}

Canada's Department of External Affairs (03.05.2013). Pobrane z: http://epe.lac-bac. gc.ca/100/206/301/faitc-aecic/history/2013-05-03/www.international.gc.ca/department/history-histoire/dcer/1954/listofpersons-en.asp

Hershberg, J. (15.01.2012). Cracking a Vietnam War Mystery. Pobrane z: https://nsarchive2.gwu.edu//NSAEBB/NSAEBB369/index.htm\#_ftn8

Hershberg, (15.01.2012). Cracking a Vietnam War Mystery: Document 4: Cable from Polish ICC Mission, Saigon (Lewandowski) to Polish Foreign Ministry (Michalowski), ciphergram no. 14596, 14 November 1966, https://nsarchive2.gwu.edu//NSAEBB/ NSAEBB369/index.htm\#_ftn8

Hershberg, (15.01.2012). Cracking a Vietnam War Mystery: Document 6: Excerpt from Polish cable from Sofia, Bulgaria, reporting on conversation between Polish Foreign Minister Adam Rapacki and Soviet leader Leonid I. Brezhnev, November 18, 1966, https://nsarchive2.gwu.edu//NSAEBB/NSAEBB369/index.htm\#_ftn8

Hershberg, (15.01.2012). Cracking a Vietnam War Mystery: Document 11: Ciphered telegram from Lewandowski in Hanoi reporting on Conversation with North Vietnamese Premier Pham Van Dong, November 25, 1966, https://nsarchive2.gwu.edu//NSAEBB/ NSAEBB369/index.htm\#_ftn8

The Telegraph (14.10.2013). Janusz Lewandowski. Pobrane z: https://www.telegraph. co.uk/news/obituaries/military-obituaries/10378441/Janusz-Lewandowski.html

United Nations (18.06.2018). Agreement of the Cessation of Hostilities in Viet-Nam 20 July 1954, Article 14c. Pobrane z: https://peacemaker.un.org/sites/peacemaker.un.org/ files/KH-LA-VN_540720_GenevaAgreements.pdf 